\title{
A case of colovesical fistula caused by the eroded rectal stent
}

\author{
Aram Barbaryan, Hadoun Jabri, Shamna Attakamvelly, Aibek E Mirrakhimov
}

Department of Internal Medicine, Saint Joseph Hospital, Chicago, Illinois, USA

\section{Correspondence to} Dr Aibek E Mirrakhimov, amirrakhimov1@gmail.com

\footnotetext{
To cite: Barbaryan $A$, Jabri H, Attakamvelly $\mathrm{S}$, et al. BMJ Case Rep Published online: [please include Day Month Year] doi:10.1136/bcr-2013009044
}

\section{DESCRIPTION}

A 59-year-old man with squamous cell carcinoma of the anus diagnosed and treated with wide local excision followed by chemotherapy and pelvic radiation in 2008 presented 4 years later with constipation. Colonoscopy revealed rectosigmoid stricture for which the patient underwent balloon dilation and colonic stent placement. Biopsy results were negative for tumour recurrence. After stent placement, the patient had been admitted several times with rectal pain with the most recent one being 1-2 months before. That time, colonoscopy did not show any stent malfunctioning, and biopsy was negative for malignancy and diverticulitis.

This time the patient presented complaining of dysuria, frequency and fecaluria accompanied by abdominal pain for several weeks. Urine analysis showed pyuria, bacteria and positive nitrite. A CT scan of the abdomen and pelvis showed urinary bladder filled with contrast and gas as well as small defect within the superior urinary bladder wall which extended to the inferior wall of the distal sigmoid colon (figure 1). Cystoscopy demonstrated a large connection between the colon and the bladder from the eroded rectal stent (figure 2). The patient subsequently underwent laparoscopic colostomy placement with plans for further repair of the fistula at a later date.

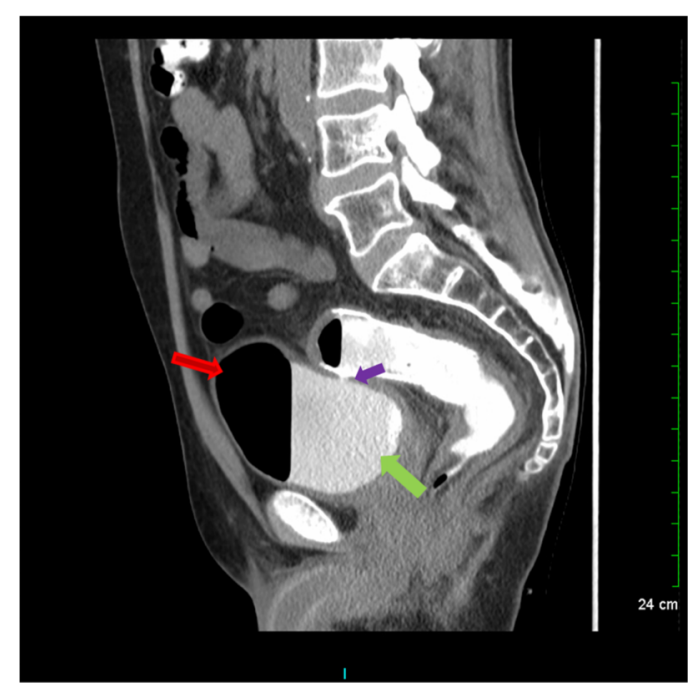

Figure 1 A CT scan of the abdomen using oral contrast agent-sagittal view. The urinary bladder is filled with contrast (green arrow) and gas (red arrow). There is also a small defect (purple arrow) within the superior urinary bladder wall which extends to the inferior wall of the distal sigmoid colon at the level of the proximal limb of the colonic stent, this is consistent with colovesical fistula. There is no pelvic adenopathy or ascites. No evidence of diverticulitis of the colon is noted.
The majority of colorectal stents are placed to relieve obstruction caused by malignancy; meanwhile, their role in benign colorectal pathology (strictures, fistulas and diverticular diseases) is less well investigated. Self-expandable metallic stents (SEMSs) were first described in the early 1990s. They have been mainly used as a definite palliative treatment and as a bridge to single-stage surgical approach. The overall technical and clinical success rate approaches above $88 \%$. Meanwhile, technical and clinical failure rates reached $8 \%$ and $5 \%$, respectively. Complication rates are less compared with palliative surgery and include stent migration (11.81\%), reobstruction (7.34\%) and perforation $(3.76 \%)$. Migration is more common with covered stents as well as after laser pretreatment, chemotherapy and benign aetiology. At the same time, covered stents are associated with less reocclusion because of tumour ingrowth. Perforation rates are higher in those studies that practiced balloon predilation $10 \%$ compared with $2 \%$ in non-dilation group. Other risk factors for perforation include excessive manipulation with the guidewire and inexperienced operators. SEMSs are considered more cost effective compared with surgical decompression. Our extensive search of the literature found only one case of colovesical fistula caused by the eroded rectal stent. Another contributing factor

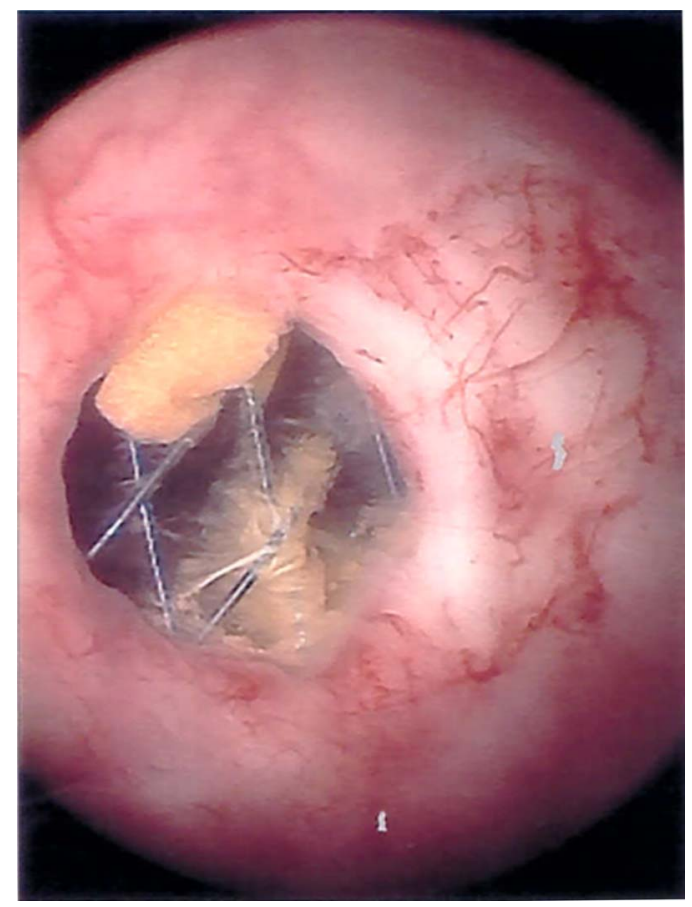

Figure 2 Cystoscopy showing the rectal stent eroded into the bladder creating a large connection between the colon and the bladder. 
for colovesical fistula formation in our case was a history of pelvic radiation. Therefore, this case is among one of those few to describe the contributory role of the rectal stent in colovesical fistula formation. ${ }^{1-3}$

\section{Learning points}

- Colovesical fistula formation can be considered as one of the major and rare complications of colorectal stents. Clinically it may present with dysuria and fecaluria.

- Self-expandable metallic stents are cost effective and have less mortality and morbidity compared with surgical approaches in treating malignant obstruction.
Competing interests None.

Patient consent Obtained.

Provenance and peer review Not commissioned; externally peer reviewed.

\section{REFERENCES}

1 Geiger TM, Miedema BW, Tsereteli Z, et al. Stent placement for benign colonic stenosis: case report, review of the literature, and animal pilot data. Int I Colorectal Dis 2008;23:1007-12.

2 Sebastian S, Johnston S, Geoghegan T, et al. Pooled analysis of the efficacy and safety of self-expanding metal stenting in malignant colorectal obstruction. $\mathrm{Am} J$ Gastroenterol 2004;99:2051-7.

3 Lopera JE, De Gregorio MA. Fluoroscopic management of complications after colorectal stent placement. Gut Liver 2010;4(Suppl 1):S9-18.

Copyright 2013 BMJ Publishing Group. All rights reserved. For permission to reuse any of this content visit

http://group.bmj.com/group/rights-licensing/permissions.

BMJ Case Report Fellows may re-use this article for personal use and teaching without any further permission.

Become a Fellow of BMJ Case Reports today and you can:

- Submit as many cases as you like

- Enjoy fast sympathetic peer review and rapid publication of accepted articles

- Access all the published articles

- Re-use any of the published material for personal use and teaching without further permission

For information on Institutional Fellowships contact consortiasales@bmjgroup.com

Visit casereports.bmj.com for more articles like this and to become a Fellow 